
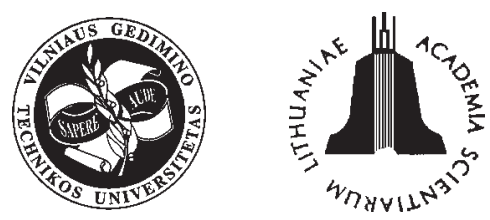

JOURNAL OF CIVIL ENGINEERING AND MANAGEMENT

http:/www.jcem.vgtu.lt

2005, Vol XI, No 2, 137-144

\title{
POLLUTANTS EMISSION FROM BUILDING MATERIALS AND THEIR INFLUENCE ON INDOOR AIR QUALITY AND PEOPLE PERFORMANCE IN OFFICES
}

\author{
Lina Šeduikyte் ${ }^{1}$, Raimondas Bliūdžius ${ }^{2}$ \\ ${ }^{1}$ Faculty of Civil Engineering and Architecture, Kaunas University of Technology, Tunelio g. 60, \\ LT-44405 Kaunas, Lithuania.E-mail: lina.seduikyte@ktu.lt \\ ${ }^{2}$ Laboratory of Thermal Building Physics, Institute of Architecture and Construction, Kaunas University of \\ Technology, Tunelio g. 60, LT-44405 Kaunas, Lithuania. E-mail: silfiz@asi.lt
}

Received 07 Feb 2005; accepted 04 Apr 2005

\begin{abstract}
New technologies and materials have introduced a large quantity of new pollutants emitted to the indoor air. Energy conservation for economical reasons, resulting in low outdoor air supply rates, can become the reason of a poor indoor air quality. The cost of the deteriorated indoor climate, resulting in reduced comfort and losses in productivity, for the society is higher than the costs for the heating energy or ventilation systems in the same building.

An experiment was conducted to determine how poor indoor air quality could cause involuntary changes in performance and occurring sick building syndrome symptoms. Twenty-four female subjects were exposed to three environmental conditions, while performing normal office tasks in a low-polluting room. Sick building syndrome symptoms, the perceived air quality and performance data were obtained. The acceptability of air quality was significantly better and the odour intensity was much lower under the conditions of high ventilation. The performance of the people, who took part in the experiment, in a two-digit addition task was significantly better under a high ventilation.
\end{abstract}

Keywords: indoor air quality, sick building syndrome symptoms, people performance, ventilation.

\section{Introduction}

\subsection{Pollutants' emission from building materials}

There has been a rapid development in building technologies, building materials, building services and energy technology over the past few decades. New technologies and materials have gained a rapid foothold since they confer evident production advantages. A similar development has taken place for fittings and furnishing materials, as well as furniture. A large quantity of new pollutants is therefore emitted to the indoor air. Finishes (floors, walls and ceilings) are considered to have an important role for the quality of the indoor air. Apart from the fact that the materials themselves can emit pollutants, they may also act as storage areas for pollutants such as particles and gases from other sources. This depot effect, which may be both positive and negative, is governed by the surface of the material. A fleecy surface (eg textile surfaces) has a large depot effect than a hard and smooth surface.

The level of the primary emission (ie the emission of different pollutants by the materials themselves) reaches the highest degree immediately after manufacture and, according to a rough estimate, this emission may be expected to diminish by $60-70 \%$ during the first six months and to disappear substantially after the first year of use. The pollutants that are emitted are solvent residues, remnants of raw materials, reaction and decomposition products from the production process as well as additives. The temperature and relative humidity of the indoor air, as well as ventilation are also significant with regard to the primary emission.

The secondary emission of pollutants is mainly caused by actions on the material. Factors that affect a material may be moisture and alkali in the building structure, high surface temperatures or different types of treatment with chemicals, such as floor cleaners, waxing, etc. The secondary emission may continuously increase and last for a very long period [1].

Owing to the fact that the primary emission has been the subject of great interest, a development towards 'low emission' materials has been noticed. This has reduced the emission of volatile organic compounds (VOCs). Over 900 VOCs have been identified in the indoor air with over 250 recorded ones at concentrations higher than 1 ppb. Some of the most commonly encountered VOCs and their sources are listed in Fig 1.

Nowadays the secondary emission is regarded as being of a greater significance. Research is needed in order to find out what are the limits of individual mate- 


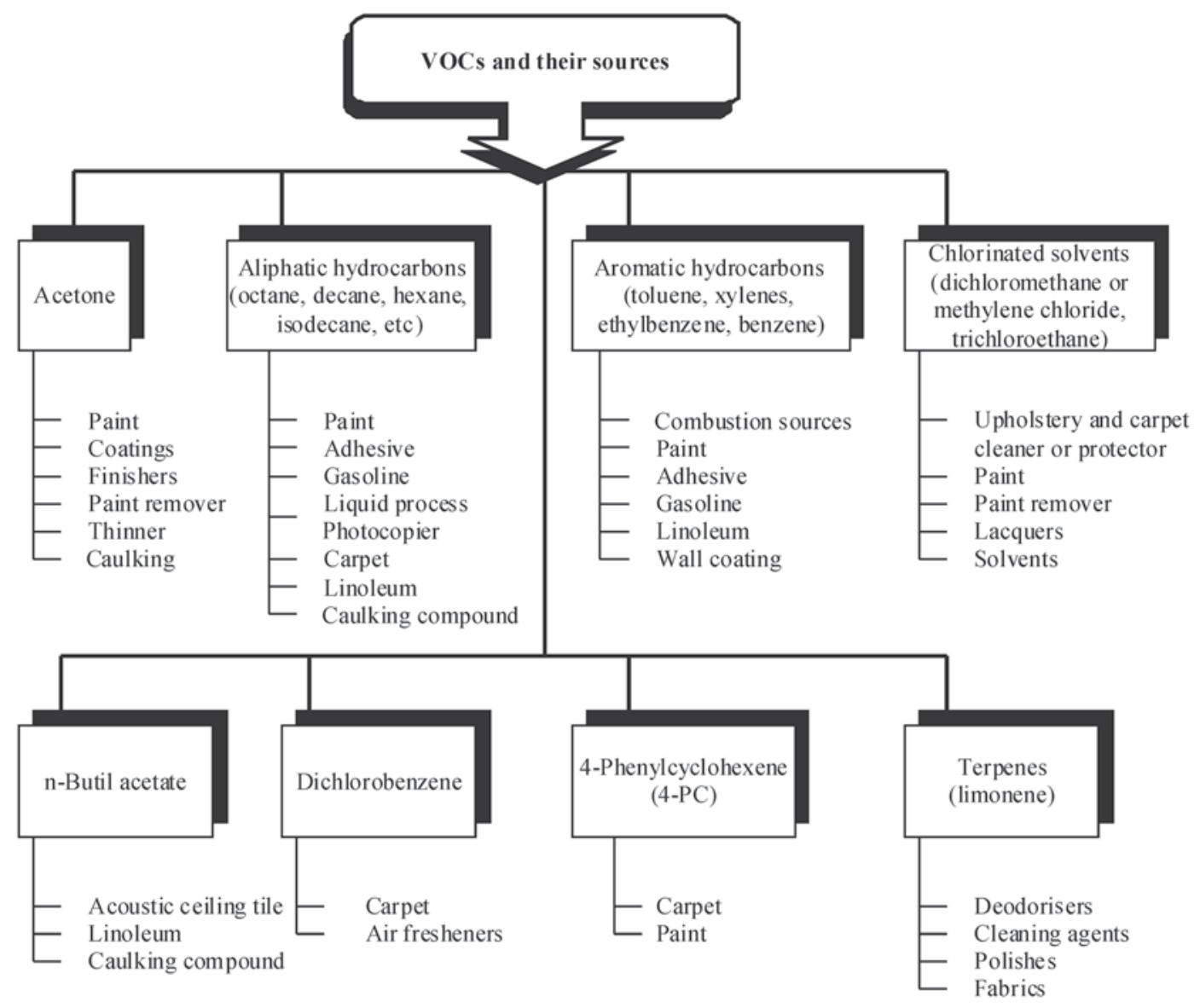

Fig 1. Commonly encountered VOCs and their sources

rials in relation to relative humidity, alkalinity, temperature etc, and what external factors are significant.

Damage can occur owing to the ignorance of conditions in the building and the lack of thought in its installation. In all cases, damage can be prevented and eliminated using the correct strategy and good quality assurance during the development of new techniques and materials, the production of building materials, design, construction and management.

Different building rating systems are proposed for evaluation of environmental performance over all building's life cycle [2].

\subsection{Ventilation of buildings}

During the last three decades ventilation philosophy experienced major changes. In the first decade of this period, considerable efforts were made towards understanding the mechanisms of air infiltration in buildings in order to control and often reduce the fortuitous ventilation and conserve energy. In some cases, the reduction in air filtration created problems associated with the air quality in buildings and the generic term 'sick building syndrome' came into being. The second decade of the same period experienced concerted efforts to understand the causes of 'sick building', which resulted in the introduction of new ventilation concepts, such as the age of air, new air quality units and a consensus for increased outdoor air flow rates. In the third decade, the emphasis on reducing energy consumption and environmental consciousness has focused the minds of researchers and designers alike on the potential of natural ventilation and user's control of the local environment. As the results of these changes, new ventilation standards and guidelines have been written to reflect the importance of ventilation on the indoor environment [3] quality.

The purpose of a ventilation system is to provide an acceptable microclimate in the space being ventilated. The microclimate refers to the thermal environment as well as the air quality. These two factors must be considered while designing a ventilation system for a room or building, as they are fundamental to the comfort and well-being of human occupants.

Human occupants produce carbon dioxide, water vapour and contaminants including biological aerosols and volatile organic compounds. By ASHRAE, comfort (odour) criteria with respect to human bioeffluents are likely to be satisfied if the ventilation results in indoor $\mathrm{CO}_{2}$ concentrations less than $700 \mathrm{ppm}$ above the outdoor air concentration [4]. ASHRAE requires 10 litres per second per person $(\mathrm{L} / \mathrm{s} / \mathrm{p})$ of the outdoor air for of- 
fices. European CR 1752 technical report (CEN, 1998) gives ventilation requirements according to the category of the office building: $\mathrm{A}-10 \mathrm{~L} / \mathrm{s} / \mathrm{p}, \mathrm{B}-7 \mathrm{~L} / \mathrm{s} / \mathrm{p}, \mathrm{C}-4$ $\mathrm{L} / \mathrm{s} / \mathrm{p}[5]$.

The view to ventilate not only for a body odour but also for any other air pollutants that potentially may cause a degradation of the perceived air quality (PAQ) was introduced by Fanger [6]. The new ventilation standards (ASHRAE, 1989) and guidelines (CEN, 1998; ECA, 1992), besides the health aspects, adopted the philosophy to ventilate for the 'acceptable indoor air quality', allowing an additional increase of the ventilation requirements due to the emission from indoor materials $[4,5$, 7]. The minimum ventilation rates provided reflect the given air quality level expressed in percentage dissatisfied, typically established between $10 \%$ and $30 \%$. These are $20 \%$ according to the US regulations (ASHRAE, 2001 [8]), while the European guideline (ECA, 1992) provides three categories of air quality corresponding to $10 \%, 20 \%$ and $30 \%$. The first category was later updated to $15 \%$ in the CR 1752 technical report (CEN, 1998), leaving the other two categories unchanged.

\subsection{Indoor environment, health and people's perfor- mance}

As the concentration of many pollutants is often higher indoors than outdoors and people spend most of their time (up to $95 \%$ ) at home and their workplaces in various buildings, there is a great possibility that a poor indoor air quality may cause a higher risk to human health and comfort than the outdoors. Indoor air quality (IAQ) in non-industrial buildings has received a special attention over the past two decades. Indoor air pollution may cause the appearance of such diseases as cancer, asthma, lung diseases, allergies and a lot of comfort-related complains.

Non-industrial indoor spaces, such as offices, schools and residences, for a long time were considered as having no harmful substances that could negatively affect human health. From the seventies, the attitude that some non-industrial buildings were related with increasing complains became popular. Health problems related to a poor indoor environment could be classified into two categories: Building Related Illnesses (BRI) and Sick Building Syndrome (SBS). BRI are caused by the exposure to biological, physical or chemical agents in the indoor environment and can be clinically diagnosed, while the appearance of SBS sometimes has no clear explanation and is related to the exposure to a particular building environment. SBS symptoms include eye, nose and throat irritation, dry, itching and red skin, headaches and mental fatigue, the sensation of dry mucous membranes, high frequency of airway infections and cough, nausea, dizziness and unspecific hypersensitivity.

The problems related to the IAQ have increased in the last two decades primarily due to the following causes:
- increase in building air tightness;

- reduction in ventilation rates to reduce energy consumption;

- increase in the use of computers, printers, photocopiers and other equipment in offices;

- increased use of textile floor covering and furnishing with high emission rate of pollutants;

- increase in the use of air-conditioning;

- lack of maintenance.

The field experiments in offices [9-11] and school [12] as well as laboratory experiments $[13,14]$ are showing that the increased ventilation rates can be effective in improving the perceived air quality and reducing SBS symptoms.

Two independent studies by Myhrvold and others in Norway [15] and by Kajtar and others in Hungary [16] found out that there were significant differences in the performance of pupils in the environments with different $\mathrm{CO}_{2}$ concentrations. In the study made by Kajtar, the $\mathrm{CO}_{2}$ concentration in the room air was manipulated using bottled gas in order to examine the influence of $\mathrm{CO}_{2}$ on the well-being and the performance of mental work. The results of this study showed that well-being and ability to sustain attention both decreased when the $\mathrm{CO}_{2}$ concentration in the air was raised to $3000 \mathrm{ppm}$ by adding bottled $\mathrm{CO}_{2}$.

The benefits of the indoor air improvement include reduced medical care cost, working days gained due to the reduced sick leave and a better performance at work.

The aim of the experiment carried out in the ICIEE was to determine whether an introduced pollution source, an old carpet, and the changed ventilation rate in the experimental office were able to affect people's performance and SBS symptoms.

\section{Methods}

\subsection{Facilities and experimental conditions}

The experiment was carried out at the International Centre for Indoor Environment and Energy, DTU, Denmark. A test room simulating a normal office (floor area: $3 \times 4=12 \mathrm{~m}^{2}$ ) was used for the experiment. This office could be described as 'low polluting' because the surface materials were selected in such a way that they would have very low emission rates. The temperature of $24{ }^{\circ} \mathrm{C}$ and relative humidity of $50 \%$ were set on control system to remain the same in all experimental conditions.

Three different environmental conditions were created for this experiment: $3 \mathrm{~L} / \mathrm{s} / \mathrm{p}$ of the outdoor air (with consequently raised bioeffluent level); $3 \mathrm{~L} / \mathrm{s} / \mathrm{p}$ with a pollution source present (a used carpet); and $20 \mathrm{~L} / \mathrm{s} / \mathrm{p}$ with no pollution source present.

The air was supplied by an axial fan mounted in the window and a second fan mounted in the window was used to remove exhaust air. By changing the dampers attached to each fan two different ventilation rates were obtained: 3 and $20 \mathrm{~L} / \mathrm{s} / \mathrm{p}$ (Fig 2). 


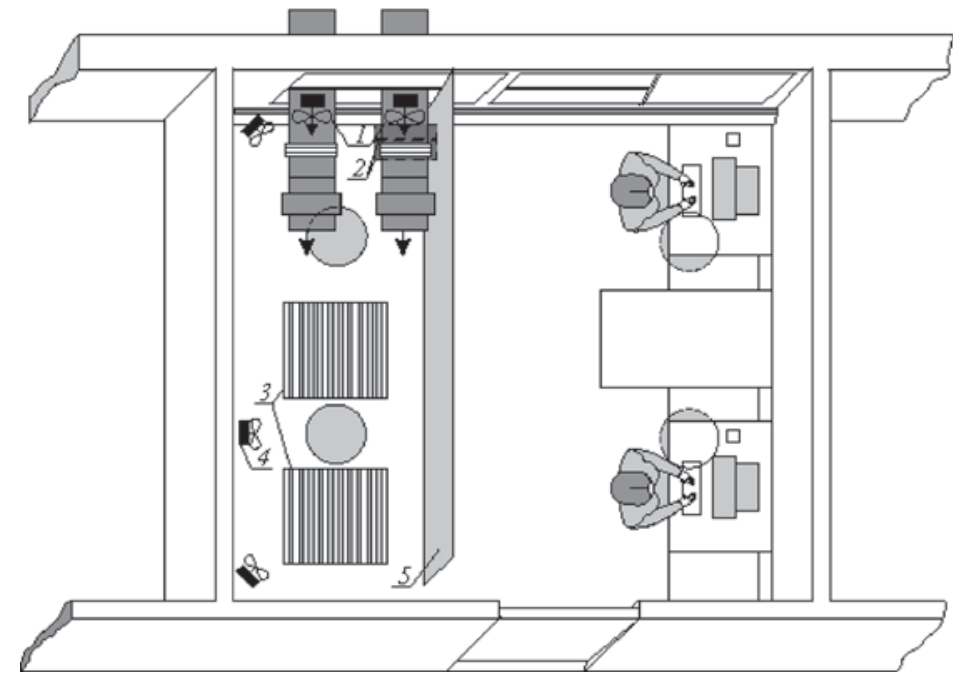

Fig 2. Experimental office: 1 - axial fans with dampers and silencers; 2 - ultrasonic humidifier; 3 - pollution source; 4 - mixing fans; 5 - partition

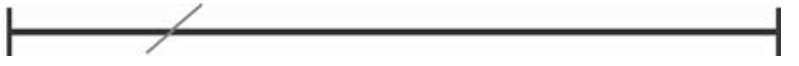

Symptoms present (0)

No symptom (100)

Fig 3. Visual analogue scales used to measure SBS symptoms

A partition was installed in the office so that the subjects were blind to the experimental conditions. The used carpet of $17 \mathrm{~m}^{2}$ was used as the pollution source. It was placed behind the partition on a stainless-steel rack and was not visible for the subjects.

Four students from the Centre occupied the experimental office for one hour before the session in order to raise the bioeffluent level each morning. It is common in all indoor environments and especially in offices that bioeffluents from other people are present. An increased concentration of bioeffluents, including $\mathrm{CO}_{2}$, was present in the two low outdoor air supply rate conditions.

\subsection{Subjects}

Twenty-four female Danish students aged 19-29 participated in the experiment. They were exposed in pairs to each of the three experimental conditions. Fifteen subjects had participated in similar experiments before, while nine of them were not familiar with such experiments.

\subsection{Physical measurements}

Temperature, $\mathrm{RH}, \mathrm{CO}_{2}$ concentration, airflow and ventilation effectiveness measurements were made continuously throughout the experiment.

\subsection{Remote performance measurement (RPM)}

RPM software was developed at ICIEE to assess human productivity in terms of the performance of standard tests. The RPM version that was used in this experiment included subjective rating scales as well as performance tests. The subjects were asked to mark the scales to indicate comfort, irritation, SBS symptom intensity, their perception of a number of environmental factors and self evaluation of a performed task.

Visual analogue scales were used to asses SBS symptoms (Fig 3). The scale is $100 \mathrm{~mm}$ long on a horizontal line without gradation, with two vertical lines marking the extreme points of the scale. The subjects put a mark on the scale, depending to what extent they agreed with the given statement.

To test different aspects of normal office work, twodigit addition, proof reading and text typing tests were used. The performance of each task was assessed in terms of the percentage of errors made and as work rate, ie the number of units attempted per hour.

On two occasions the subjects were asked to complete additional questionnaires, marking visual-analogue scales to indicate their assessment of air quality, odour intensity and irritations (Fig 4).

Just after they had entered the experimental office and adjusted their chair as well as at the end of the experiment, after re-entering the office after spending 5$10 \mathrm{~min}$ outside to refresh their olfactory sense.

For performing the data analysis for subjective ratings, the linear scales were coded as following:

Acceptability scale: 'clearly acceptable' $=+1$; 'clearly unacceptable' = -1; 'just acceptable / just unacceptable' $=+0,01 /-0,01$.

Odour intensity scale: 'no odour' = 0; 'slight odour' $=1$; 'moderate odour' $=2$; 'strong odour' $=3$; 'very strong odour' $=4$; 'overpowering odour' $=5$. 
Imagine you during your daily work would be exposed to this air

How do you assess the air quality?

Please mark on the scale!

Pay attention to the distinction between acceptable and unacceptable!

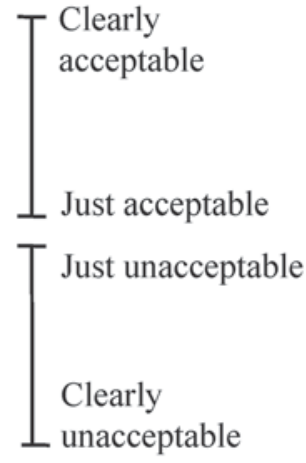

Assess irritation in intensity

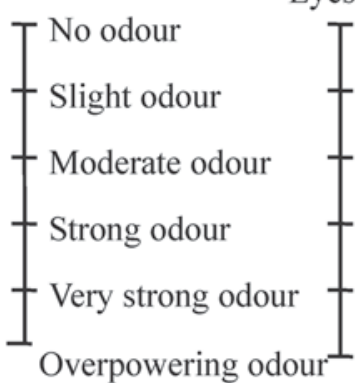

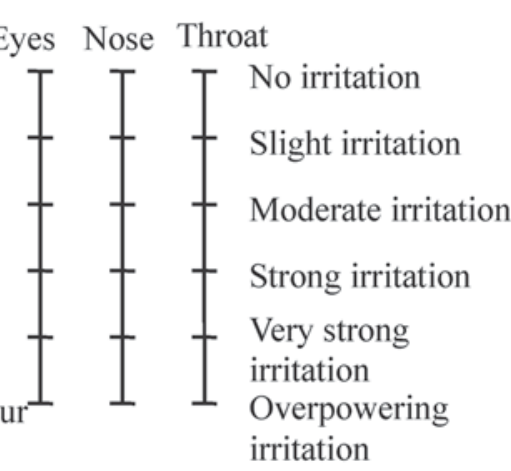

Fig 4. Questionnaires to indicate assessment of air quality, odour intensity and irritations in the experimental office

Irritation scales: 'no irritation' = 0; 'slight irritation' $=1$; 'moderate irritation' $=2$; 'strong irritation' $=3$; 'very strong irritation' $=4$; 'overpowering irritation' $=5$.

The percentage dissatisfied with the perceived air quality was calculated as a measure of the perceived air quality in the office. The mean ratings of acceptability were transformed to percentage dissatisfied using equation (1) based on the data by Gunnarsen and Fanger:

$$
P D=\frac{e^{-0,18-5,28 \cdot A C C}}{1+e^{-0,18-5,28 \cdot A C C}} \cdot 100,
$$

where:

PD - percentage of dissatisfied with the air quality, $\%$; ACC - mean vote of air acceptability.

The subjects were informed that they should have adjusted their clothing to maintain thermal neutrality throughout the experiment.

\subsection{Statistical analyses}

The data were analysed with SPSS 11 for Windows using the non-parametric Friedman test. If an overall tendency approaching significance $(\mathrm{P}<0,1)$ was found, the Wilcoxon Matched-Pairs Signed Ranks test was used to test the significance of differences between the pairs of conditions $(\mathrm{P}<0,05)$. These are both within-subjects tests that assume no more than an ordinal level of measurement and neither requires that the data be normally distributed.

\section{Results}

Although the control system was intended to maintain a constant temperature of $24^{\circ} \mathrm{C}$ and a relative humidity of $50 \%$, some temperature and $\mathrm{RH}$ variations occurred during the experiment, which are presented in Table 1.
Table 1. Average temperature, $\mathrm{RH}$ and $\mathrm{CO}_{2}$ concentration values

\begin{tabular}{l|c|c|c}
\hline $\begin{array}{c}\text { Experimental } \\
\text { conditions }\end{array}$ & $\mathrm{t},{ }^{\circ} \mathrm{C}$ & $\mathrm{RH}, \%$ & $\begin{array}{c}\mathrm{CO}_{2} \text { outdoor, } \\
\mathrm{ppm}\end{array}$ \\
\hline $\begin{array}{l}3 \mathrm{~L} / \mathrm{s} / \mathrm{p}+ \\
\text { Pollution }\end{array}$ & $23,72 \pm 0,17$ & $48,98 \pm 3,43$ & $421 \pm 4,91$ \\
\hline $3 \mathrm{~L} / \mathrm{s} / \mathrm{p}$ & $23,68 \pm 0,19$ & $48,85 \pm 3,57$ & $430 \pm 5,21$ \\
\hline $20 \mathrm{~L} / \mathrm{s} / \mathrm{p}$ & $23,44 \pm 0,23$ & $42,44 \pm 3,45$ & $448 \pm 4,21$ \\
\hline
\end{tabular}

$\mathrm{CO}_{2}$ concentration in the experimental condition when the ventilation rate was $3 \mathrm{~L} / \mathrm{s} / \mathrm{p}$ of the outdoor air was almost treble compared with $20 \mathrm{~L} / \mathrm{s} / \mathrm{p}$ (Fig 5).

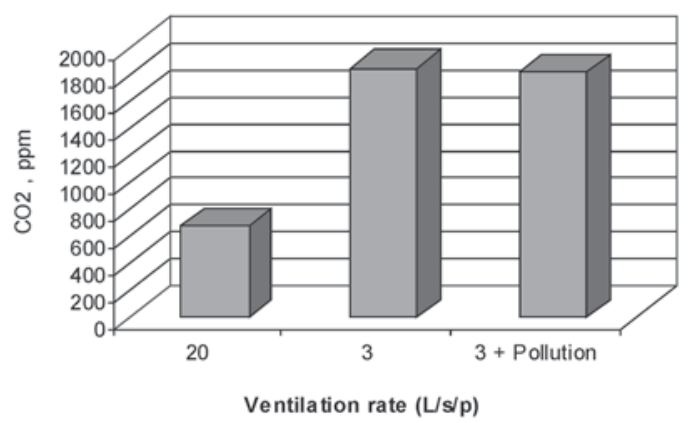

Fig 5. Average $\mathrm{CO}_{2}$ concentrations in the experimental office

The acceptability of the air quality was significantly better in the condition with a high ventilation than with a low ventilation $(\mathrm{P}<0,0001)$ or a low ventilation and the pollution source present $(\mathrm{P}<0,0001)$. The presence of the carpet did not significantly affect the acceptability ratings in the two conditions of a low ventilation $(\mathrm{P}>0,3805)$.

The percentage dissatisfied with the perceived air quality, calculated from the acceptability ratings, is shown in (Fig 6). 
Odour intensity (Fig 7) as well as nasal irritation were significantly higher both in the condition with a low ventilation $(\mathrm{P}<0,0001)$ and with a low ventilation and the pollution source present $(\mathrm{P}<0,0001)$ compared with the high ventilation condition. At the end of the exposure, throat irritation was indicated as significantly higher $(\mathrm{P}<0,011)$ in the condition with $3 \mathrm{~L} / \mathrm{s} / \mathrm{p}+$ Pollution than $20 \mathrm{~L} / \mathrm{s} / \mathrm{p}$.

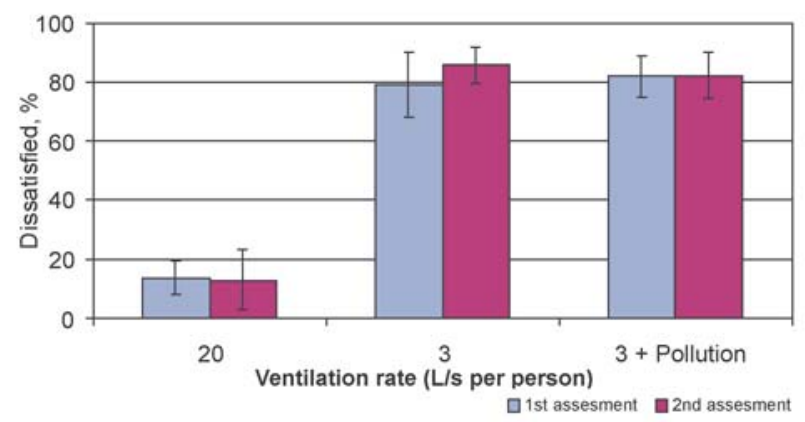

Fig 6. Percentage of dissatisfied with the perceived air quality after entering the office ( $1^{\text {st }}$ assessment) and after re-entering the office at the end of exposure $\left(2^{\text {nd }}\right.$ assessment)

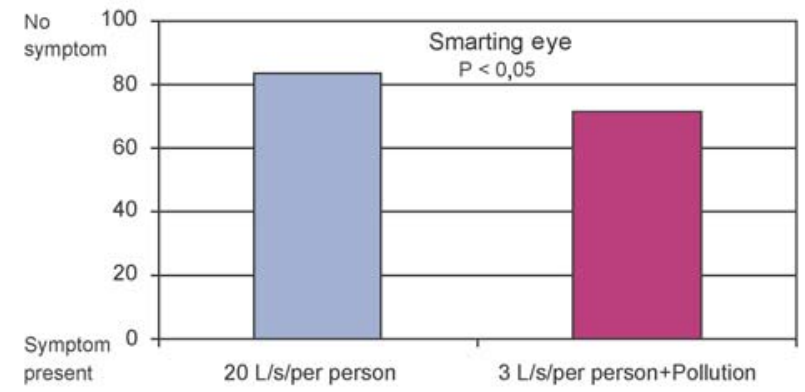

Difficulty in thinking $(\mathrm{P}<0,0442)$ and smarting eyes $(\mathrm{P}<0,0209)$ (Fig 8) were significantly worse in the condition with a low ventilation and the pollution source present than in the condition with a high ventilation.

The subjects made a significantly higher percentage of errors $(\mathrm{P}<0,0353)$ when performing the second twodigit addition task in the condition of $3 \mathrm{~L} / \mathrm{s} / \mathrm{p}$ (with raised bioeffluent level) than $20 \mathrm{~L} / \mathrm{s} / \mathrm{p}$ (Fig 9).

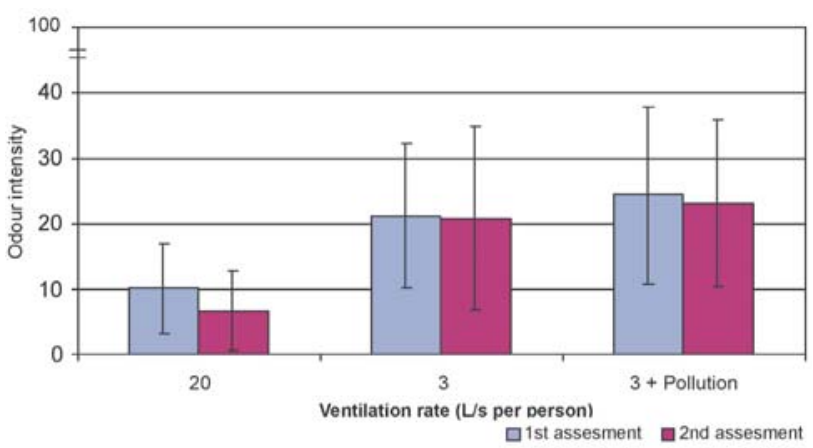

Fig 7. Odour intensity under three experimental conditions $(0=$ 'no odour', $100=$ 'evaporating odour')

Fig 8. SBS symptoms indicated under different experimental conditions

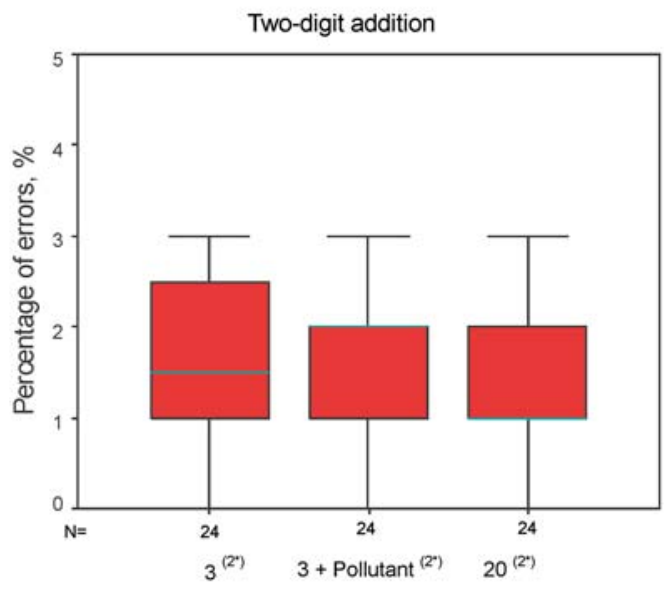

Ventilation rate (L/s per person)

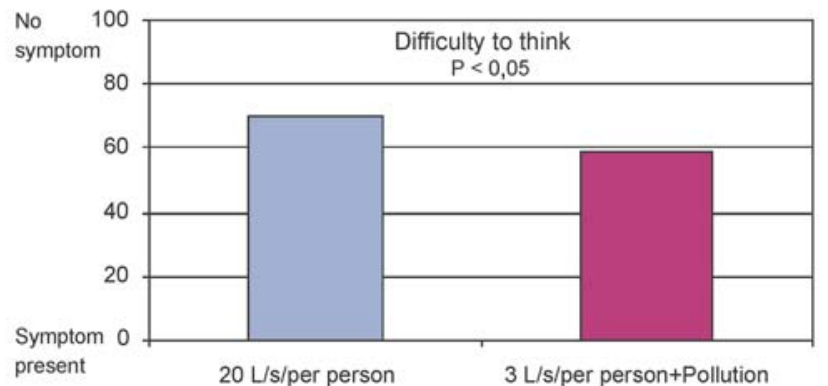


The results obtained for the 'trained' subjects who participated in the previous experiment show that a significantly $(\mathrm{P}<0,0416)$ higher percentage of errors occurred in the second two-digit addition task in the $3 \mathrm{~L} / \mathrm{s} / \mathrm{p}$ condition (with raised bioeffluent level) than in the $20 \mathrm{~L} / \mathrm{s} / \mathrm{p}$ condition.

Text typing speed was significantly $(\mathrm{P}<0,0285)$ lower in the $3 \mathrm{~L} / \mathrm{s} / \mathrm{p}$ (with raised bioeffluent level) than in the $20 \mathrm{~L} / \mathrm{s} / \mathrm{p}$ condition (Fig 10).

New subjects made significantly more errors performing the proof reading task in the $3 \mathrm{~L} / \mathrm{s} / \mathrm{p}$ condition when the carpet was not present, contrary to expectations. However, as this sub-group is very small $(\mathrm{N}=9)$ this is likely to be a chance result. Thus no significant differences between the conditions were observed in work rate in the two-digit addition or proof reading tasks.

\section{Discussion}

The secondary emission of pollutants from the carpet, which was used as a pollution source, affected the appearance of SBS symptoms. The subjects indicated such symptoms as smarting eyes and difficulty in thinking as significantly more present in the condition with low ventilation and the pollution source present while compared with the condition with a high ventilation.

The subjects who took part in the experiment representing able-bodied individuals were performing normal office work worse in the condition with poor IAQ (evaluated by percentage of errors and work rate).

IAQ can be improved with a reduced pollution source or an increased ventilation rate. Although economical factors arising with the increased energy use are important, priority should be given to better IAQ, as it will give reduce in medical care cost, increase of working days because of better health and would not decrease the performance of office work.

\section{Conclusions}

1. The perceived air quality improved and the odour intensity decreased when the ventilation rate was increased and the pollution source was removed. The percentage dissatisfied with the perceived air quality decreased by $65 \%$ when ventilation rate was increased.

2. Low ventilation is insufficient to reduce $\mathrm{CO}_{2}$ concentration and other pollutants. With low level of the outdoor air in the experimental office $\mathrm{CO}_{2}$ concentration was 1829 ppm, which was 2,71 times higher compared with $20 \mathrm{~L} / \mathrm{s} / \mathrm{p}$.

3. The deteriorated indoor climate in the experimental office is related to SBS symptoms. Difficulty in thinking and smarting eyes were identified as significantly more intensive in the condition with low ventilation and the pollution source present than in the condition with high ventilation.
4. Decreased ventilation rate from 20 to $3 \mathrm{~L} / \mathrm{s} / \mathrm{p}$ increased the average percentage of errors made by experimental subjects by $17,4 \%$ while performing two digit addition task, and reduced typed symbols by $5,5 \%$. The performance of several tasks improved with a better air quality.

5. The right choice of the outdoor air supply rate when pollution sources from building materials, office equipment and the occupants working in the office are evaluated, will result in good IAQ and better performance.

\section{Acknowledgments}

This work has been supported by the Danish Technical Research Council (STVF) as a part of the research programme of the International Centre for Indoor Environment and Energy established at the Technical University of Denmark for the period 1998-2007. Thanks are also to supervisors Wyon D.P. and Wargocki P. and collaborators Bakó-Biró Zs. and Barna E.

\section{References}

1. Indoor environment and health. National Institute of Public Health. Berlings Skogs, Trelleborg, Sweden, 1999. 92 p.

2. Šaparauskas, J. Multiple criteria evaluation of buildings with emphasis on sustainability. Journal of Civil Engineering and Management, Vol IX, No 4, 2003, p. 234-240.

3. Awbi, H. B. Ventilation of buildings. TJ International Ltd, Padstow, Cornwall, Great Britain, 2003. 522 p.

4. ASHRAE Standard 62-1989. Ventilation for acceptable indoor air quality. American Society of Heating, Refrigerating and Air-Conditioning Engineers, Atlanta, USA, 1989. $33 \mathrm{p}$.

5. CEN Technical Report CR 1752. Ventilation for Buildings: design criteria for the indoor environment. European Committee for Standardization, Brussels, 1998. 73 p.

6. Fanger, P. O. Introduction of the olf and decipol units to quantify air pollution perceived by humans indoors and outdoors. Energy and Buildings, Vol 12, Issue 1, 1988, p. 1-6.

7. ECA (European Concerted Action 'Indoor Air Quality and Its Impact on Man'). Guidelines for ventilation requirements in buildings. Report No 11, Office for Publications of the European Communities, Luxembourg, 1992. 37 p.

8. ASHRAE Standard 62-2001. Ventilation for acceptable indoor air quality. American Society of Heating, Refrigerating and Air-Conditioning Engineers, Atlanta, USA, 2001, p. 33 .

9. Jaakkola, J. J. K.; Heinonen, O. P. and Seppanen, O. Mechanical ventilation in office buildings and Sick Building Syndrome. An experimental and epidemiological study. Indoor Air, Vol 2, No 5, 1991, p. 111-121.

10. Nagda, N. I.; Koontz, M. D. and Albrecht R. J. Effects of ventilation rate in a healthy building. In: Proceedings of the ASHRAE/ICBRSD conference of IAQ'91, Atlanta, 
USA, 18-21 Nov 1991. Ed by Geshwiler M., Montgomery L., Moran M., 1991, p. 101-107.

11. Sundell, J. On the association between building ventilation characteristics, some indoor environmental exposures, some allergic manifestations and subjective symptom reports. Indoor Air, Suppl 2, 1994, p. 101-113.

12. Hanssen, S. O. Increased ventilation reduces general symptoms but not sensory reactions. In: Proceedings of the 6th International Conference on Indoor Air Quality and Climate, Vol 5, Helsinki, Finland, 4-8 July, 1993, p. 33-38.

13. Wargocki, P.; Wyon, D. P.; Sundell, J.; Clausen, G. and Fanger, P. O. The effects of outdoor air supply rate in an office on Perceived Air Quality, Sick Building Syndrom (SBS) symptoms and productivity. Indoor Air, Vol 10, No 4, 2000, p. 222-236.
14. Bako-Biro, Z.; Wargocki, P.; Weschler, C. J. and Fanger, P. O. Effects of pollution from personal computers on perceived air quality, SBS symptoms and productivity in offices. Indoor Air, Vol 14, No 3, 2004, p. 178-187.

15. Myhrvold, A. N.; Olsen, E. and Lauridsen, O. Indoor environment in schools - pupils' health and performance in regard to $\mathrm{CO}_{2}$ concentrations. In: Proceedings of the 6th International Conference on Indoor Air Quality and Climate, Vol 4, Nagoya, Japan, 21-26 July, 1996, p. 369-374.

16. Kajtar, L.; Herczeg, L. and Lang, E. Examination of influence of $\mathrm{CO}_{2}$ concentration by scientific methods in the laboratory. In: Proceedings of the 7th International Conference Healthy Buildings, Singapore, 7-11 Dec, 2003. Ed by Tham Kwok Wai, Sekhar C., Cheong D. CD version, p. $176-181$.

\section{STATYBINIUU MEDŽIAGU TERŠALŲ EMISIJA IR JŲ POVEIKIS BIURO PATALPŲ ORO KOKYBEI IR ŽMONIŲ DARBINGUMUI}

\section{L. Šeduikytė, R. Bliūdžius}

Santrauka

Nagrinejjami didžiausią ịtaką patalpų mikroklimatui turintys veiksniai - pirminė ir antrinè teršalų emisija iš statybinių, apdailinių medžiagų ir patalpų vėdinimo lygis. Netinkamos mikroklimato sąlygos daro poveiki žmonių savijautai ir darbingumui. Sumažèjęs žmonių darbingumas, atsiradusios sveikatos problemos gali turèti ir ekonominių padarinių. Atliekant laboratorinị eksperimentą tirtas pasirinkto teršalų šaltinio keičiant védinimo lygi poveikis patalpų oro kokybei, žmonių savijautai ir darbingumui. Atlikta eksperimento rezultatų statistinė analizė. Pateikiami tyrimo metodai patalpų oro kokybès, žmonių darbingumo ir „sergančio“ pastato sindromo simptomams ịvertinti.

Raktažodžiai: patalpų oro kokybè, teršalų emisija iš statybinių medžiagų, „sergančio“ pastato sindromas, žmonių darbingumas.

Lina ŠEDUIKYTĖ. PhD student at the Faculty of Civil Engineering and Architecture, Kaunas University of Technology, Lithuania. Her research interests include thermal-comfort parameters, pollutants emission from building materials, effects of indoor air quality on health, SBS symptoms and performance of office work.

Raimondas BLIŪDŽIUS. Senior research fellow at the Laboratory of Thermal Building Physics at the Institute of Architecture and Construction, Kaunas University of Technology, Lithuania. The main research areas include physical properties of building materials, research of physical-technical processes in building envelopes. 